\title{
Implementasi sistem kearsipan sebagai faktor determinan efisiensi kerja pegawai
}
(The implementation of filing system as a determinant factor efficiency of employee work)

\author{
Pradhilla Mahandani Soehana', Uep Tatang Sontani ${ }^{2^{*}}$ \\ 1,2Program Studi Pendidikan Manajemen Perkantoran, \\ Fakultas Pendidikan Ekonomi dan Bisnis, Universitas Pendidikan Indonesia, \\ Jl. Dr. Setiabudhi, No. 229 Bandung, Jawa Barat Indonesia \\ Email: ueptatangsontani@upi.edu
}

\begin{abstract}
ABSTRAK
Bertolak dari kerangka acuan teori dan logika serta pendapat para pakar, bahwa hasil kerja pegawai tidak dapat di abaikan dari peran instrumen sebagai faktor supporting di samping kemampuan dan motivasi dari pegawai itu sendiri. Terlebih lagi bahwa penyelesaian pekerjaan tidak hanya sekedar efektif tetapi juga efisien. Efisiensi kerja pegawai dalam berbagai organisasi telah menjadi suatu tuntutan yang tidak bisa diabaikan. Sistem kearsipan merupakan instrumen supporting bagi terwujudnya efisiensi kerja. Dapat dikatakan bahwa efiensi kerja pegawai tergantung salah satunya pada sistem yang di berlakukan dalam bekerja, terutama pada tataran implement-tasinya. Untuk hal tersebut hasil survey dan analisis data penelitian pada salah satu Instansi Pemerintahan di Kota Bandung ternyata hipotesis penelitian terjawab bahwa implementasi sistem kearsipan merupakan salah satu faktor determinan yang memiliki pengaruh cukup kuat terhadap efisiensi kerja pegawai.
\end{abstract}

Kata Kunci: Implementasi sistem kearsipan; efisiensi kerja.

\begin{abstract}
Starting from the framework of reference theory and logic and opinions of experts, that the work of employees can not be ignored from the role of the instrument as a supporting factor in addition to the ability and motivation of the employees themselves. Moreover, the completion of work is not only effective but efficient. The efficiency of the work of employees in various organizations has become a demand that can not be ignored. Filing system is a supporting instrument for the realization of work efficiency. It can be said that the effectiveness of the employee depends on one of them on the system in practice, especially at the level of implementation. For that result survey results and analysis of research data in one Government Institution in Bandung was the research hypothesis was answered that the implementation of filing system is a strong enough support to the efficiency of employee work.
\end{abstract}

Keywords: Implementation of archival systems; efficiency of employee work.

Received: Agustus 2018, Revision: November 2018, Published: Januari 2019 


\section{PENDAHULUAN}

Permasalahan efisiensi dewasa ini menjadi isu yang menarik untuk dikaji. Permasalahannya antara lain adalah belum optimalnya efisiensi kerja seperti yang terjadi di salah satu Instansi Pemerintahan di Kota Bandung. Efisiensi kerja pegawai merupakan salah satu faktor yang mempunyai peranan penting di dalam berbagai macam kegiatan organisasi. Oleh karena itu hal tersebut sangat perlu diperhatikan dan diusahakan pencapaiannya secara sungguh-sungguh. Efisiensi kerja tidak hanya tercermin dari hasilnya saja akan tetapi tercermin juga dari pemanfaatan biaya dan waktu yang lebih hemat. Efisiensi kerja bagi organisasi merupakan hal yang mutlak untuk terus diusahakan dengan berbagai cara. Efisiensi kerja merupakan ukuran terhadap prestasi organisasi. Organisasi yang belum efisien berarti organisasi tersebut belum sukses, organisasi tersebut masih menghadapi masalah. Seperti halnya yang terjadi pada salah satu Instansi Pemerintahan di Kota Bandung, dimana Instansi Pemerintahan tersebut masih menghadapi masalah yaitu belum optimalnya efisiensi kerja. Hal tersebut tentunya menjadi pekerjaan rumah yang harus di selesaikan. Upaya yang perlu dilakukan untuk menyelesaikan permasalahan tersebut adalah dengan menelusuri faktor-faktor yang berhubungan dan diduga sebagai faktor penyebab munculnya masalah tersebut.

Pada dasarnya terdapat berbagai faktor yang mempengaruhi keberhasilan efisiensi kerja, antara lain: faktor lingkungan fisik dan faktor lingkungan sosial. Lingkungan kerja yang memotivasi bagi karyawan perusahaan yang bersangkutan akan dapat meningkatkan gairah kerja. Lingkungan kerja yang dapat memotivasi para karyawan perusahaan akan mendorong para karyawan untuk bekerja dengan sebaik-baiknya, sehingga pelaksanaan proses produksi di dalam perusahaan tersebut akan dapat berjalan dengan baik pula (Ahyari, 1994). Yang dimana salah satu dari faktor lingkungan sosial yaitu gaya manajemen. Manajemen sebagai suatu sistem sosial, atau dengan perkataan lain, sebagai suatu sistem interelasi budaya. Ia berorientasi secara sosiologis, berurusan dengan berbagai kelompok sosial dan hubungan-hubungan budayanya serta berusaha menyatukan kelompok-kelompok ini ke dalam suatu sistem sosial (Terry, G. R. dan Leslie W. Rue, 2005). Dan Bidang Manajemen Perkantoran terdiri dari (1) Office Space (Ruang Kantor); (2) Communication (Komunikasi); (3) Office Personal (Kepegawaian Kantor); (4) Furniture and Equipment (Perabotan dan Perlengkapan); (5) Appliances and Machines (Peralatan dan Mesin); (6) Supplies and Stationery (Perbekalan dan Keperluan Tulis); (7) Methods (Metode); (8) Records (Warkat/Arsip); (9) Executive Control (Kontrol Pejabat Pimpinan) Charles O. Libbey (Sedarmayanti, 2001). Lalu peran sumber daya manusia berperan penting di dalam pengimplementasian sistem kearsipan di dalam suatu organisasi. Pentingnya nilai sumber daya manusia yang dianggap sebagai sumber daya yang paling diakui dan diidentifikasi dari sebuah organisasi (Ingrid \& Augustin, 2014). Analisis kehidupan organisasi dilihat dari tiga faktor utama, yaitu: (1) perilaku (individu, kelompok, organisasi), (2) struktur (desain organisasi), dan (3) proses komunikasi dan pengambilan keputusan (Gibson 2012).

Secara teoritis banyak faktor yang mempengaruhi efisiensi kerja pegawai, salah satunya adalah implementasi sistem kearsipan. Dengan adanya sistem penyimpanan warkat yang tepat, tata kerja kearsipan yang baik dan tata penyingkiran warkat yang tertib dapatlah terlaksana pengurusan arsip yang efisien dalam setiap organisasi. Oleh sebab itu pengelolaan kearsipan yang baik merupakan langkah awal untuk meningkatkan efisiensi kerja (Istiqomah, 2015).

Secara khusus penelitian ini mempertanyakan faktor yang mempengaruhi efisiensi kerja pegawai, dengan melakukan pembatasan variabel yaitu implementasi sistem 
kearsipan, dan mengetahui seberapa besar pengaruh implementasi sistem kearsipan terhadap efisiensi kerja pegawai.

\section{TINJAUAN PUSTAKA}

\section{Efisiensi Kerja Pegawai}

Efisiensi adalah melakukan pekerjaan dengan benar (doing things right), sedangkan efektivitas adalah melakukan pekerjaan yang benar (doing the right things) Peter Drucker (T. Hani Handoko, 2013). Efisiensi merupakan salah satu parameter kinerja yang secara teoritis mendasari seluruh kinerja sebuah organisasi. Kemampuan menghasilkan output yang maksimal dengan input yang ada adalah merupakan ukuran kinerja yang diharapkan. Efisiensi berkaitan dengan penggunaan sumber daya untuk mencapai tujuan. Suatu aktifitas dapat dikatakan efisien apabila dapat memeroleh hasil yang sama dengan aktivitas lain tetapi sumber daya yang digunakan lebih sedikit (Antya Sukmawati, 2013).

Efisiensi kerja merupakan kemampuan untuk menyelesaikan suatu pekerjaan dengan benar. Ini merupakan konsep matematik, atau perhitungan rasio antara keluaran (output) dan masukan (input). Seorang yang dapat bekerja secara efisien adalah seseorang yang mendapatkan hasil pekerjaan (output) yang lebih tinggi (hasil, produktivitas, performance) dibandingkan dengan modal yang dikeluarkan untuk melakukan perkerjaan tersebut (tenaga, bahan, uang, mesin, dan waktu). Dengan kata lain, seorang pegawai dapat meminimumkan biaya penggunaan sumber daya untuk mencapai keluaran yang dapat ditentukan disebut efisiensi. Atau hasil pekerjaan pegawai dikatakan efisien apabila dapat memaksimumkan keluaran dengan jumlah masukan yang terbatas (Nunuk Herawati \& Nika Aprilia Sahanti, 2009). Dalam suatu organisasi efisiensi kerja menjadi salah satu faktor pendorong bagi organisasi yaitu mencapai tujuan bersama (Dina Rolanna Simanungkalit \& Lucy Anna, 2012). Efisiensi dianggap sebagai sarana untuk mencapai tujuan organisasi, efisiensi yang tinggi diinginkan oleh manajemen agar organisasi mereka dapat mencapai efektivitas yang tinggi juga (Wantania, Yohana I. \& Lapian, Stanss L.H.V. Joyce, 2015).

Variabel Efisiensi Kerja Pegawai diukur melalui lima indikator sebagai berikut: (1) Pemakaian pikiran termudah; (2) Pemakaian tenaga teringan; (3) Pemakaian waktu tercepat; (4) Pemakaian ruang terdekat; (5) Pemakaian benda termurah (The Liang Gie, 2009).

\section{Implementasi Sistem Kearsipan}

Arsip dinyatakan dengan istilah "file", yang berasal dari bahasa latin fehon yang berarti tali alau benang. Pada awalnya orang-orang Inggris menyatukan warkat dengan cara mengikatnya dengan tali atau benang. Dalam bahasa Arab disebut "warkat" yang berarti surat (Rianto Ritonga \& Tasha Ratna Dewanthi, 2010). Menurut International Standard Organization (ISO 2001) mendefinisikan arsip catatan sebagai informasi yang dibuat, diterima dan dipelihara sebagai bukti dan informasi oleh organisasi atau orang yang sesuai dengan kewajibannya hukum atau dalam transaksi bisnis. Catatan yang diawetkan atau disesuaikan untuk pelestarian oleh lembaga atau penerus sah sebagai bukti fungsinya, kebijakan, prosedur, keputusan, operasi atau kegiatan lain atau karena ada nilai dalam informasi yang terkandung di dalamnya (Ladan, 2014). Arsip adalah segala sesuatu yang tertulis, bergambar dan terekam yang berisikan penjelasan mengenai suatu hal atau informasi dari suatu peristiwa yang digunakan untuk membantu ingatan dan/atau dapat dijadikan pedoman. Arsip merupakan salah satu informasi manajemen yang sangat penting dalam kegiatan administrasi maupun pelaksanaan tugas suatu lembaga. Ketersediaan arsip 
yang efektif, efisien, lengkapdan berkualitas merupakan tuntutan yang tidak dapat diabaikan (Emi Jumiyati, 2011).

Sistem adalah himpunan dari unsur-unsur yang saling berkaitan sehingga membentuk suatu kesatuan yang utuh dan terpadu (Ifansyah, 2005). Sistem pengelolaan arsip memegang peranan penting bagi jalannya suatu organisasi yaitu sebagai sumber informasi dan sebagai pusat ingatan organisasi yang dapat bermanfaat untuk bahan penilaian, pengambilan keputusan, atau penyusunan program pengembangan dari organisasi yang bersangkutan (H.M. Nawawi Dg. Sibali, 2010). Sistem kearsipan digunakan untuk menyimpan arsip dalam suatu basis data yang sewaktu waktu dapat dipanggil, diubah, dan disimpan kembali (Dessy Irmawati \& Yuniar Indrihapsari, 2014)

\section{Pengaruh Implementasi Sistem Kearsipan Terhadap Efisiensi Kerja Pegawai}

Setiap pegawai yang bekerja di dalam suatu organisasi tentunya tidak akan terlepas dari dokumen-dokumen yang membantu di dalam proses penyelesaian pekerjaan tersebut. Adapun dokumen-dokumen tersebut dapat diolah ataupun disimpan menggunakan sistem tertentu tergantung dengan kebutuhan dari organisasi. Karena dengan pengelolaan sistem kearsipan yang baik akan mempengaruhi hasil pekerjaan pegawai menjadi lebih cepat, tepat sasaran, dan dapat memenuhi persyaratan ekonomis atau penghematan dengan kata lain akan memenuhi persyaratan efisiensi kerja.

Agar arsip dapat memberikan informasi secara maksimal, maka diperlukan pengelolaan kearsipan yang baik dan teratur. Sehingga akan membantu pimpinan dalam merencanakan dan mengambil keputusan, selain itu juga dapat menghemat waktu, tenaga, fikiran dan biaya. Dengan demikian pengelolaan kearsipan dikantor harus ditingkatkan guna menunjang peningkatan produktivitas dan efisiensi kerja kantor (Valine Mei Maengkom, Jantje. Mandey, \& Gustaf Tampi, 2015).

Berdasarkan pada tinjuan pustaka yang sudah dibahas maka kerangka pemikiran dalam kajian ini adalah sebagai berikut:

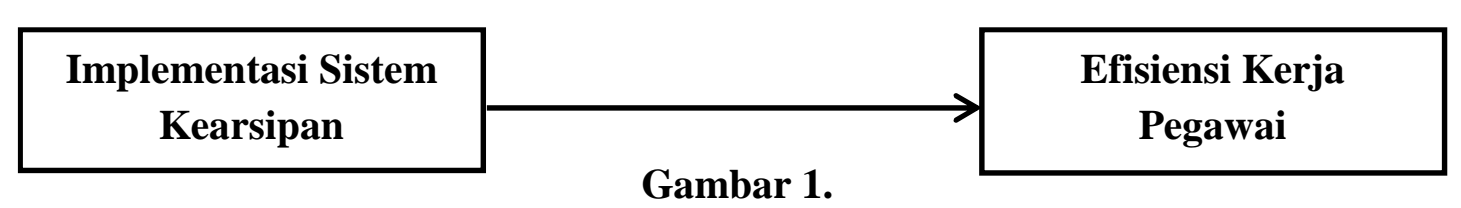

\section{Theoritical Framework}

Hipotesis : Terdapat pengaruh implementasi sistem kearsipan terhadap efisiensi kerja pegawai.

\section{METODE PENELITIAN}

Penelitian ini dilakukan dengan mengunakan metode explanatory survey method karena menggunakan angket (kuesioner) sebagai alat pengumpul datanya. Sebagaimana yang dijelaskan oleh Sambas Ali M dan Uep Tatang S (2011) bahwa metode penelitian survey adalah "Metode penelitian yang digunakan terhadap sejumlah individu atau unit analisis, sehingga ditemukan fakta atau keterangan secara faktual mengenai gejala atau kelompok atau perilaku individu, dan hasilnya dapat digunakan sebagai bahan pembuatan rencana atau pengambilan keputusan. Penelitian metode survey ini merupakan studi yang bersifat kuantitatif dan umumnya survey menggunakan kuesioner sebagai alat pengumpul datanya". 
Teknik pengumpulan data yaitu dengan pengumpulan angket dengan model rating scale yang dengan rentang antara 1 sampai 5 dengan responden penelitian yang berjumlah 116 orang di salah satu Instansi Pemerintahan di Kota Bandung. Teknik analisis data yang digunakan adalah regresi sederhana dan korelasi product moment.

Instrumen pengumpulan data berupa angket tersebut terdiri dari 2 bagian yaitu angket untuk mengukur efektifitas implementasi sistem kearsipan yang terdiri dari 6 indikator, diantaranya kesederhanaan, ketepatan, memenuhi persyaratan ekonomis, penempatan yang strategis, sistem yang digunakan harus fleksibel, dan menjamin keamanan. Serta angket untuk mengukur tingkat efisiensi kerja pegawai yang terdiri dari 5 indikator, diantaranya pemakaian pikiran termudah, pemakaian tenaga teringan, pemakaian waktu tercepat, pemakaian ruang terdekat, dan pemakaian benda termurah.

Berdasarkan pendahuluan tinjuan pustaka pada penelitian ini, bertujuan untuk mengetahui pengaruh implementasi sistem kearsipan terhadap efisiensi kerja pegawai. Selanjutnya berdasarkan pendahuluan dan tinjauan pustaka dapat dikembangkan menjadi sebuah hipotesis penelitan yaitu terdapat pengaruh implementasi sistem kearsipan terhadap efisiensi kerja pegawai, yang kemudian gambaran dari tanggapan responden mengenai efektifitas implementasi sistem kearsipan dan tingkat efisiensi kerja pegawai diperoleh dengan statistik deskriptif mengunakan skor rata-rara tiap bagian. Kemudian teknik analisis untuk menguji hipotesis penelitian menggunakan analisis regresi.

\section{HASIL PENELITIAN DAN PEMBAHASAN}

\section{Efisiensi Kerja Pegawai sebagai Determinan dari Implementasi Sistem Kearsipan}

Berdasarkan hasil pengumpulan dan pengolahan data dari jawaban angket responden. Gambaran persepsi responden mengenai efektifitas implementasi sistem kearsipan di salah satu Instansi Pemerintahan di Kota Bandung berada pada katagori Cukup Baik, hal ini mengindikasikan bahwa efektifitas pengimplementasian sistem kearsipan sudah cukup baik. Selanjutnya mengenai gambaran persepsi tingkat efisiensi kerja pegawai berada pada kategori tinggi, hal ini mengindikasikan bahwa tingkat efisiensi kerja pegawai dalam bekerja harus bisa dipertahankan dan akan lebih baik lagi bila bisa ditingkatkan.

Teknik analis data yang digunakan dalam penelitian ini adalah regresi sederhana dengan uji $\mathrm{F}$. Kriteria pengujian hipotesis yaitu jika $\mathrm{F}_{\text {hitung }}>\mathrm{F}_{\text {tabel }}$ maka $\mathrm{H}_{0}$ ditolak dan $\mathrm{H}_{1}$ diterima apabila $\mathrm{F}_{\text {hitung }}<\mathrm{F}_{\text {tabel }}$ maka $\mathrm{H}_{0}$ diterima dan $\mathrm{H}_{1}$ ditolak.

Hasil pengolahan data statistik didapatkan persamaan regresi $\tilde{y}=28.7382+0.4336 x$ persamaan tersebut mengandung makna keduanya berjalan searah artinya jika implementasi sistem kearsipan ditingkatkan, maka efisiensi kerja pegawai akan meningkat. Nilai $F_{\text {hitung }}$ sebesar 49.2680 sedangkan nilai dari $F_{\text {tabel }}$ dengan tingkat kesalahan $\alpha=0.05$ $\mathrm{db}_{1}=\mathrm{k}=1$ dan $\mathrm{db}_{2}=\mathrm{n}-\mathrm{k}-1=114$ yaitu sebesar 3.9243, dapat dilihat bahwa nilai $\mathrm{F}_{\text {hitung }}$ $>\mathrm{F}_{\text {tabel }}(49.2680>3.9243)$ maka Hipotesis diterima. Sehingga dapat disimpulkan bahwa hipotesis terdapat pengaruh implementasi sistem kearsipan terhadap efisiensi kerja pegawai terbukti.

Besarnya hubungan antara variabel implementasi sistem kearsipan dengan efisiensi kerja pegawai dapat dihitung dengan menggunakan korelasi product moment hasilnya sebesar 0.5493 , besaran koefisien korelasi tersebut berada pada kategori hubungan yang sedang sehingga dapat disimpulkan bahwa implementasi sistem kearsipan memiliki hubungan sedang dengan efisiensi kerja pegawai. Koefisien determinasi variabel implementasi sistem kearsipan terhadap efisiensi kerja pegawai yang diperoleh yaitu sebesar $30 \%$, dan sisanya sebesar $70 \%$ dipengaruhi oleh faktor lain yang tidak diteliti 
dalam penelitian ini. Dengan demikian kontribusi implementasi sistem kearsipan cukup kuat terhadap efisiensi kerja pegawai.

\section{KESIMPULAN}

Implementasi sistem kearsipan merupakan faktor determinan efisiensi kerja pegawai. Hal tersebut dapat bermakna bahwa setiap peningkatan efektifitas implementasi sistem kearsipan maka tingkat efisiensi kerja pegawai juga akan meningkat pula. Korelasi yang sedang/cukup kuat antara implementasi sistem kearsipan dengan efisiensi kerja pegawai. Dengan demikian implikasi yang dapat diambil dalam upaya meningkatkan efisiensi kerja pegawai yang lebih baik, perlu adanya peningkatan efektifitas implementasi sistem kearsipan yang lebih baik juga dan berkelanjutan.

\section{DAFTAR PUSTAKA}

Ahyari, Agus. (1994). Manajemen Produksi. Yogyakarta : BPFE UGM.

Jumiyati, Emi. (2011). Sarana Dan Prasarana Kearsipan Di Pusat Teknologi Bahan Bakar Nuklir Batan

Gibson, et al. (2012). Organizations: Behaviour, structure, processes, fourteenth edition. New York: The McGraw-Hill Companies, Inc.

Handoko, T. Hani. (2013). Manajemen. Yogyakarta : BPFEE (edisi kedua)

Herawati, Nunuk \& Sahanti, Nika Aprilia. (2009). Analisis Efisiensi Penggunaan Modal Kerja Perusahaan dengan Rasio Keuangan pada PT. Gudang Garam, Tbk Tahun $2005-2009$.

H.M. Nawawi Dg. Sibali. (2010). Penerapan Sistem Kearsipan pada Kantor Arsip Daerah Kabupatan Kutai Barat, 6.

Ifansyah, Muhammd Noor \& Wartini, Munati. (2005). Implementasi Sistem Kearsipan Pada Dinas Pekerjaan Umum Kabupaten Barito Timur.

Ingrid, M., \& Augustin, A. (2014). A Study on Impact of Human Resource Accounting in Educational Istitution with Special References to Bangalore City Colleges. European Scientific Journal, 193 - 206.

Irmawati, Dessy \& Indrihapsari, Yuniar. (2014). Sistem Informasi Kearsipan Untuk Meningkatkan Kualitas Pelayanan

Istiqomah, Hendrayadi Agus, \& Yudiatmaja Wayu Eko. 2015. Pengaruh Pengelolaan Kearsipan terhadap Efisiensi Kerja pada Dinas Sosial dan Tenaga Kerja Kota Tanjung Pinang.

Ladan, A. (2014). Management and Utilisation of Judicial Records in Federal High Courts in Northwestern States of Nigeria. Procedia - Social and Behavioral Sciences, 147, 32-38. 
Rianto Ritonga \& Tasha Ratna Dewanthi. (2010). Pemahaman tentang Kearsipan Meningkatkan Efektifitas dan Kreatifitas Karyawan terhadap Pengelolaan Arsip (Studi Kasus pada PT Karuniasteel Anta Surya).

Simanungkalit, Dina Rolanna \& Anna, Lucy. (2012). Analisis Hubungan Kerjasama Tim untuk Meningkatkan Efisiensi Kerja pada PT Mitha Samudera Wijaya Medan.

Sedarmayanti. (2001). Manajemen Sumber Daya Manusia dan Produktifitas Kerja. Bandung : CV. Mandar Maju.

Sukmawati, Antya. (2013). Analisis Efisiensi Penggunaan Belanja dan Jumlah Pegawai terhadap Indeks Kepuasan Masyarakat: Studi pada Satuan Kerja Perangkat Daerah Kota Malang Tahun 2013.

Terry, G. R. dan Leslie W Rue. (2005). Dasar-Dasar Manajemen. Jakarta : Bumi Aksara.

The Liang Gie. (2009). Administrasi Perkantoran Modern. Yogyakarta : Liberty.

Sontani, Uep Tatang dan Muhidin, Sambas Ali. (2011). Desain Penelitian Kuantitatif. Bandung : Karya Andhika Utama.

Valine Mei Maengkom, Jantje. Mandey, dan Gustaf Tampi. (2015). Pengaruh Pengelolaan Kearsipan Terhadap Efisiensi Kerja Pegawai Negeri Sipil Di Kantor Perwakilan Badan Pengawasan Keuangan Dan Pembangunan Propinsi Sulawesi Utara, 3.

Wantania, Yohana I. \& Lapian, Stanss L.H.V. Joyce. (2015). The Effect Of Employee Morale And Facilities Toward Employee Efficiency Of Pt Astra International Tbk - Daihatsu Manado. Vol.3 No.3. 